University of Nebraska - Lincoln

DigitalCommons@University of Nebraska - Lincoln

Faculty Publications, UNL Libraries

Libraries at University of Nebraska-Lincoln

3-1-1999

\title{
The Collegial Environment and the Functional Organization
}

Mary K. Bolin

University of Nebraska--Lincoln, mbolin2@unl.edu

Follow this and additional works at: https://digitalcommons.unl.edu/libraryscience

Part of the Library and Information Science Commons

Bolin, Mary K., "The Collegial Environment and the Functional Organization" (1999). Faculty Publications, UNL Libraries. 40.

https://digitalcommons.unl.edu/libraryscience/40

This Article is brought to you for free and open access by the Libraries at University of Nebraska-Lincoln at DigitalCommons@University of Nebraska - Lincoln. It has been accepted for inclusion in Faculty Publications, UNL Libraries by an authorized administrator of DigitalCommons@University of Nebraska - Lincoln. 


\title{
The Collegial Environment and the Functional Organization
}

\author{
Mary K. Bolin
}

SUMMARY. Libraries are generally organized by function in order to carry out their mission efficiently. A cademic librarians who are faculty also have a collegial organization that exists apart from any functional arrangement. Public and technical services librarians in this sort of organization are colleagues who have responsibility for the library in the way that teaching faculty are responsible for the programs in their departments. This article discusses the characteristics of the successful collegial organization and the relationship of technical and public services librarians in a collegial library. [Article copies available for a fee from The Haworth Document Delivery Service: 1-800-342-9678. E-mail address: getinfo@ haworthpressinc.com <Website: http://www.haworthpressinc.com>]

KEYWORDS. Organizational change, academic libraries, library organization, library administration, technical services, public services, collegiality

\section{INTRODUCTION}

"Everything is assigned and nothing is assigned" -this paradox is at the heart of Allen Veaner's "last word" on the subject of academic librarianship. ${ }^{1}$ Librarians have what he terms "programmatic responsibilities" and "programmatic leadership" which operate from a "node of power and influ-

[Haworth co-indexing entry note]: "The Collegial Environment and the Functional Organization." Bolin, M ary K. Co-published simultaneously in J ournal of Library Administration (The Haworth Information Press, an imprint of The Haworth Press, Inc.) Vol. 29, No. 2, 1999, pp. 49-61; and: Integration in the Library Organization (ed: Christine E. Thompson) The Haworth Information Press, an imprint of The Haworth Press, Inc., 2000, pp. 49-61. Single or multiple copies of this article are available for a fee from The Haworth Document Delivery Service [1-800-342-9678, 9:00 a.m. - 5:00 p.m. (EST). E-mail address: getinfo@ haworthpressinc.com].

E 2000 by The Haworth Press, Inc. All rights reserved. 
ence," rather than deferentially and self-effacingly responding only to perceived or expressed needs. ${ }^{2}$ This paradigm demands that librarians be able to think subtly, tolerate ambiguity, make a distinction between themselves and non-librarians, and take responsibility for something that is not a "list of tasks" but a program. ${ }^{3}$

Veaner dismisses the idea that organizational models such as teams or matrices are the key to achieving the paradigm that he describes. He does not speak directly to the explosive issue of faculty status for academic librarians. $M$ oreover, it is not necessary for academic librarians to be faculty for them to assume responsibility and leadership in the way that Veaner describes. B ut implied in his dismissal of the organizational experiments and his argument for programmatic responsibility is the separation of functional arrangement from the library's professional or collegial organization.

The issue of faculty status for librarians has been talked to death, with a lot of heat, but also with some light having been shed. $M$ any of the arguments against it make points that must be dealt with, including the strained comparisons between librarianship and teaching, and the implication that librarians must assume a false identity in order to gain respect. The many versions of some sort of faculty status which exist in different institutions make it impossible to say that it has been a success, a failure, or something in-between. However, the paradigm described by Veaner can work, and it can work in the collegial environment that is necessary for librarians to be successful faculty.

A ll organizations are imperfect. Some organizations may have a functional arrangement that impedes service, and changing that arrangement may improve service. Nevertheless, even the best functional organization will not prevent incompetence, mediocrity, and failure, because the baggage that each person brings to a workplace guarantees that no organization can be made perfectly efficient or perfectly anything. A collegial library organization will have its share of imperfection and irrationality as well.

This article describes the characteristics of the successful collegial organization and the interaction between the collegial library faculty and the library functions, and particularly the traditional technical and public services.

\section{HISTORICAL SETTING}

A cademic libraries share an environment with higher education in general. This has been described at length many times: the competition for scarce resources, the demand for accountability from governing bodies and citizens, the rapid technological development, and the new players providing even more competition. In this environment, the academic library is trying to find its place, just as colleges and universities in general are doing. Within the 
library, public services departments are asking what "reference" might be these days, bibliographers ponder the concept of a "collection," and technical services examines the very nature of "acquiring" and giving "access" to information.

Taking a step backward, the most recent iteration of faculty status for academic librarians arose during a time when higher education was looking at governance arrangements. ${ }^{4}$ The changes to higher education in the late 1960s and shortly after represented a reaction against top-dow $n$ management, and products of that time include student evaluation of teaching, newlycreated or revived faculty senates, and a generally more participative climate. The desire of librarians to take their place in this reshaped collegial model is represented by the Association of College and Research Libraries (ACRL) documents on faculty status. ${ }^{5}$

\section{The Collegial Organization}

As the name implies, the collegial organization consists of faculty who are colleagues, without regard for specific position. This form of organization grew and developed over a long period of time as colleges and universities evolved, and is a model designed for the scholarly pursuits of teaching and the activities that accompany it. A lthough many people work for the university, only the faculty members belong to the collegial organization. The collegial organization makes recommendations on promotion and tenure, has responsibility for the curriculum for each program, and carries out governance responsibilities through departmental, college, and university-wide committees.

W hile academic freedom and faculty governance are crucial characteristics of the collegial organization, there are checks on faculty authority. The university administration and governing boards have the ultimate authority in budget allocation and decision-making. Students, alumni, accrediting agencies, legislative bodies, and citizens all have authority or influence as well. To glamorize or romanticize the idea of being faculty is to misunderstand or deny its messy reality, especially in today's climate, which is often critical of, if not adversarial toward, the traditions of higher education.

\section{THE TEACHING DEPARTMENT}

Faculty in a teaching department ${ }^{6}$ are assigned courses by the department head, with participation, negotiation, cajoling, bargaining, and so on. There are many issues involved in this assignment, including the interests and expertise of the faculty member and the needs of the department and university. However, once the teaching load is assigned, the faculty member is 
responsible for the course as it is officially described in the catalog, and independent and autonomous within the confines of political and academic reality. The faculty member's scholarship usually relates in some way, to a greater or lesser extent, to the courses taught.

The role of teaching and the nature of scholarship are being debated on many campuses. The model of scholarship proposed by Ernest Boyer has been influential. ${ }^{7}$ Boyer proposes four kinds of scholarship: of discovery, integration, application, and teaching. This model attempts to give faculty from different departments and disciplines different kinds of scholarship that best fit their subject, assignment, and talents. The attention in recent years to the role of teaching and the value of different kinds of scholarship shows that teaching faculty are not monolithic and by no means universally satisfied with the status quo.

\section{THE COLLEGIAL LIBRARY}

The library faculty, i.e., the librarians only, constitute the collegial library organization. Without regard for functional differences, library faculty make promotion and tenure recommendations, and have responsibility for the library, as if it were the curriculum in a teaching department. Library faculty have research and service as an integral part of their assignment.

The library situation is comparable to the teaching department in a number of ways. Reference, cataloging, collection management, and so on, are assigned, balancing library needs with faculty expertise and ability. Library faculty may not necessarily enjoy the autonomy of teaching faculty, how ever. They may be observed and monitored at the reference desk by their colleagues, constrained beyond necessity not only by the supposed requirements of shared cataloging standards but by local procedures, and by pressure from teaching faculty to manage the collection in a certain way. The view of librarianship as "service" with its connotation of response and reaction may constrain us as well. On the other hand, teaching faculty have "interference" and constraints as well, including the need to have satisfactory student evaluation scores, pressure to maintain or increase enrollment, and so on.

The Boyer model of scholarship is useful for librarians. The research interests of librarians can grow out of the applied research they do routinely, in which "the library is the laboratory." 8 The work of the academic librarian can be the raw material for the scholarship of application. Far from needing "release time" to do research, librarians have the potential for a close relationship between library assignment and the research that can grow out of it, so that scholarship is integrated with librarianship, and is not a discrete "add-on."

One complex problem is the role of managers and administrators in the 
collegial organization. While teaching departments are relatively flat, the departmentalization and increased administration that came with the rise of the modern university in the nineteenth century brought a more specialized and hierarchical arrangement to all parts of the university. ${ }^{9}$ The academic library grew more specialized and hierarchical as modern librarianship grew along with the modern university. Tucker describes the role of the academic department head as a "first among equals" who nevertheless has administrative responsibilities such as planning, budgeting, evaluation, and faculty development. ${ }^{10}$ B loss and $L$ anier have described a similar set of responsibilities for library department heads, even in a non-traditional functional organization. ${ }^{11}$

In some of the most important and influential recent literature on the academic library organization, $M$ itchell and $M$ orton emphasize the need for library faculty to be acculturated to the scholarly life, ${ }^{12}$ Veaner describes the set of attitudes necessary for librarians to have a paradigm of "programmatic responsibility," 13 and $\mathrm{Hill}$ describes the characteristics of librarianship as a profession and how those characteristics relate to the collegial model.14 These three articles provide the complete conceptual framework for a successful collegial and functional organization for academic librarians.

Despite the existence of these well-reasoned and persuasive roadmaps to a collegial library, there is hardly a sorer topic in academic librarianship than the question of faculty status for librarians. There are a number of valid criticisms to be made of the faculty model for librarians, but one real reason for the bitterness and strife that surround this issue is in the implementation it has received in various libraries. There may be conceptual difficulties with the model, but ambiguity and even contradiction are more easily tolerated than bad management. Modern academic librarianship grew up with the modern university, and their origins have much in common, but the problem with faculty status for librarians is failure of library administrators to make a real commitment to it and provide a supportive environment. The brilliant systematizing of M elvil Dew ey had an obvious human resources agenda-the oppressive, prescriptive "busyness" that still afflicts many libraries today. $\mathrm{N}$ or is this limited to libraries. Rudolph remarks of the rise of industrialized "academic man" in the early twentieth century, "the cult of efficiency sustained the old paternal purposes." 15

Debate on faculty status centers on the supposed conflict between the demands of library service (the functional organization) and of scholarship and faculty governance. One common objection is the supposed need for librarians to work a conventional weekly and daily schedule. A nother objection is present but not often stated: the traditional egalitarianism of many librarians that makes them reluctant to make a point of the difference between themselves and other library employees. Implicit also is the insecurity of 
some librarians regarding their qualifications, scholarly and professional. Both these qualities are part of the lack of socialization into the scholarly outlook, which makes some librarians reject the idea of being faculty. Selffulfilling prophecies that result from this are the view that faculty activity will interfere with "real work," and the perception that teaching faculty do not accept librarians as colleagues.

The collegial organization demands that librarians view themselves as scholars in charge of a program, rather than technicians who have mastered a skill, even a complex and important skill. It demands that they be willing to make a sharp distinction between the responsibilities they have as faculty and the responsibilities of other library employees who are not faculty. It demands that they deal with faculty from outside the library as peers. Why are these demands difficult? They may be difficult in themselves, but they are also in conflict with the actual values of many libraries. It is not surprising that librarians resent the idea of faculty status when it often has been implemented so badly.

\section{TECHNICAL SERVICES}

There are particular problems and benefits for technical services librarians in the collegial organization. The first problem for technical services is the idea that academic librarianship is a form of "teaching." Wilson describes this pervasive and facile analogy as an "organization fiction" by which librarians rationalize the fact that they are often perceived negatively, controlling scarce resources. ${ }^{16}$ She dismisses educational differences and other factors in analyzing why teaching faculty reject the notion that librarians are teachers, seeing the reason as simply that they can see no similarity between teaching and librarianship.

A ckerman states that the " $[A C R L]$ Statement on Faculty Status of College and University Librarians (1975), .... [t]aken at face value, ... . excludes librarians without substantial teaching and research functions from faculty status," although in a second document, "The Standards for Faculty Status of College and U niversity Librarians ... by accepting professional responsibilities in particular areas of competence . . . they blanket in all librarians." 17 Despite the more inclusive language of the second document, this concept of librarianship as a form of teaching underlies the way the profession has conceived and argued for faculty status.

Hill counters this notion, including among the "characteristics of librarianship" the concepts of librarianship as "an academic discipline in its ow right," with "its own foundation of theory and practice," the basis for which is "organization, evaluation, and provision of access to information." 18 This is the workable and acceptable conceptual basis for a collegial library; how- 
ever, the persistent "backroom" image and resulting lower status of technical services has not changed substantially despite all the changes of the last thirty years. This can be exacerbated in the collegial organization if librarians are thought to be faculty because of a strained comparison between librarianship and teaching, based on the superficial resemblance between reference and library instruction and some of the activity of teaching departments. M cG owan illustrates both the weakness of the comparison and the persistent backroom role assigned to technical services by proposing a clinical model for library faculty as an improvement over the "librarianship as teaching" analogy. ${ }^{19}$ She compares reference librarians to medical school clinicians who treat patients, and assigns technical services librarians the role of radiologist or pathologist in this analogy. (This gives new meaning to the term "dead serial.")

Especially when there is a "librarianship as teaching" analogy, public services, particularly reference, may be viewed as the default library service, the norm to which all others are compared. This presents two problems for technical services. O ne is that, while acquisitions, cataloging, and so on, may have a constrained and narrowly defined mission and scope, reference and instruction may grow to include every new service or new way of delivering service. This leaves technical services faculty out in the cold, and may lead to the second problem, which is that they are felt to be missing something at promotion and tenure time, since they may have shared neither in the "default" service nor in any innovations in service.

Technical services is production-oriented, and has an almost industrial quality to the flow of material from placing an order to sending an item to the shelf. Like all of librarianship during its modern history, it is task- or methodoriented. M oreover, the so-called "deprofessionalization" of cataloging and other technical services functions has caused a sort of identity crisis for some technical services librarians. A ctivities that were once the province of professional librarians are now done by non-librarians, resulting in increased prominence and responsibility for paraprofessional staff. This is not incompatible with a collegial organization, however. The task-oriented nature of the workflow does not imply that the work of technical services librarians is merely Veaner's abhorred "list of tasks." 20 "D eprofessionalization" can be a kind of "reprofessionalization," in which staff are highly-skilled and able to take over many of the complex but ultimately routine tasks and much of the supervision, leaving technical services librarians to act as planners, managers, problem-solvers, and experts on difficult cases.

The expertise of the faculty is crucial to defining the functions and their relationship to each other in the collegial organization. Looking beyond task-based technical skill does not mean that knowledge and experience are not important. Catalog librarians must be expert catalogers, from knowledge 
of the MARC format to an understanding of the principles of bibliographic control in its broadest sense. Reference librarians, subject bibliographers, acquisitions and serials librarians, all must bring confident expertise to the library program. The heart of scholarship is the love of a subject and the mastery of it. True expertise would allow collegial librarians to create their own ad hoc matrix or team organization, and change it at will. M oreover, just as the collegial library is responsive, but does not merely react to outside demands, technical services librarians in the collegial organization do not merely react to demands from public services but take initiative in planning their part of the library program.

W hile both Hill and Veaner characterize libraries as generally hierarchical, and Veaner emphasizes the hierarchical nature of the university, technical services departments are traditionally more hierarchical than public services departments, particularly reference departments. Technical services librarians often see promotion to a supervisory or department head position as a sign of progress in a career, whereas reference librarians may find themselves jockeying for position in a flat, undifferentiated department. In the collegial organization, promotion consists not of receiving a supervisory assignment, but promotion in rank, to Associate or full Professor or the equivalent. Like teaching faculty, librarians in the collegial organization can "progress" by attaining higher ranks through demonstrating increasing expertise in some aspect of librarianship and the accompanying research and service. This increasing expertise might include supervisory or managerial responsibility, but that is by no means the only kind of "progress."

The collegial organization may require managers to rethink their roles as well. Staff have supervisors, because supervisors manage a given task or group of tasks. Faculty members do not have supervisors, because they are colleagues in charge of a program. Department heads may find that their promotion or tenure is being voted on by faculty in their departments, who report (functionally) to them. Not only that, but if managerial positions are overvalued in the traditional functional organization, they may be undervalued in the collegial one. Good management is the key to a successful organization, and department heads must show leadership among library faculty, despite the fact that they are not "supervisors" of faculty.

Hill lists as one of the characteristics of libraries that they are "service organizations." $21 \mathrm{Her}$ point in saying this includes the idea that an academic library serves the needs of a particular institution and designs services to match the needs of that one institution. While that may be true, the hard-todeny idea of libraries as a "service" may do more harm than any other truism about libraries. If librarianship is a service, then, in the minds of many, technical services serves public services. This idea interacts with the idea of (public services) librarian as teacher in a way that is potentially very damag- 
ing to technical services. The library is not a "service" any more than the English Department is a "service" to students of agriculture and engineering, or any more than any enterprise of any kind is a "service." This view of librarianship as "service" will not allow programmatic leadership or responsibility as described by Veaner. A s it is implemented, giving service sometimes turns into being servile, of which C. S. Lewis remarks, "By a 'servile' man ... we mean an abject, submissive man who cringes and flatters. That is not the ancient idea ... the true servile character is cheeky, shrewd, cunning, up to every trick, always with an eye to the main chance. . . . "22 The emphasis on librarianship as service often leads to servility in both the senses described: worshipful, cringing adulation of Dr. Smith, and his demands, and a decidedly uncollegial feeling toward him when he is not around. Technical Services suffers in this situation, since all the blame and none of the gratitude for "service" can be directed there.

\section{WORKLOAD AND ASSIGNMENT}

"Everything is assigned and nothing is assigned," but faculty must still have workable assignments. This array of assignments will form the basis for annual performance evaluation and for collegial evaluation for promotion and tenure. The missions defined by many universities are teaching, research, and service and faculty workload is divided among these three areas. These three missions can be adapted and adopted by a library faculty. Each librarian would be assigned a portion of librarianship, with research and service being left to the initiative of the individual. This assignment is the mechanism for innovation, because "assignment" is assignment of a responsibility, not a task. The librarianship assignment would consist only of cataloging for some librarians, of reference and instruction for some, of reference, instruction, and collection development for others, of administration or management of a function for some, and so on.

The meaning of research is more obvious, although the definition of scholarly activity is being discussed on many campuses. In any case, for a truly collegial organization and genuine faculty status, librarians must embrace scholarship and the idea that they are scholars.

"Service" is used to mean many things, and can be especially ambiguous if librarianship is defined as a service. Service for faculty members includes the activities of regional and national professional organizations, as well as participation in faculty governance at the local level. Service on campus with other faculty colleagues is essential for a successful collegial library organization.

It is ironic that one of the critiques of faculty status that has been made is that library faculty are evaluated for promotion and tenure primarily on their assignment in librarianship rather than on research activities. If this is true, we are ahead of the game for once. One issue for teaching faculty in recent 
years has been the need for each faculty member to be evaluated on the percentages of teaching, research, and service assigned to each individual, rather than making decisions primarily based on research output, which may be a small percentage of the entire workload.

\section{TIME AND SPACE}

One aspect of "assignment" is the difficult and literal one: how much? Teaching faculty may have percentages of time devoted to each function. The percentage of time devoted to teaching will correspond to the part of the department's curriculum that is assigned to each faculty member, and may be nearly identical for each person, or may vary according to factors such as the level of student being taught. The percentage of time assigned to teaching includes explicitly named courses, and implicitly includes preparation, office hours and other time to meet with students, etc.

L ibrarianship assignments can mimic this situation to a certain extent. The hours devoted to reference and instruction can be divided among reference librarians, equally or according to some formula or special arrangement. That assignment can include explicitly scheduled hours and implicit activity such as preparation, individual reference and instruction for patrons who request it, preparation of instructional materials, and so on.

This type of assignment is somewhat different for technical services librarians. While cataloging was scheduled to a certain degree in the days when one went "to the terminal," those days are gone, with cataloging software installed on the desktop computer of each cataloger. Therefore, while catalogers can be assigned a portion of the cataloging workload, by language, format, subject, etc., and while that explicit assignment can have implicit activities such as solving problems, assigning call numbers, and so on, this is not the same as having a defined number of hours of reference or instruction. Whereas reference and library instruction are scheduled and predictable, the stream of items to be cataloged never dries up. There is also a danger that a cataloger could simply never catalog since it is unscheduled. Kingma and M cCombs discuss workload in analyzing the "opportunity costs" for faculty status, estimating the amount of work that is "lost" when librarians engage in research and other scholarly activities. ${ }^{23}$ Time spent on one thing cannot be spent on another, but the notion expressed by K ingma and $\mathrm{M} \mathrm{cCombs}$ that a certain number of books would have been cataloged, for example, for every hour that a librarian spends instead on research, or anything else, is dubious.

The view that library faculty have no time, or very little time, to engage in scholarship is widely accepted. Hill characterizes library faculty as being like those teaching faculty who have a heavy teaching load. ${ }^{24} \mathrm{M}$ itchell and $\mathrm{M}$ orton emphasize the fact that being a faculty member is "not a forty-hour job." 25 
These two assertions are probably true, but they disguise something at the heart of the rancor many librarians feel about faculty status. Even teaching faculty with "heavy course loads" are free to manage their time outside the classroom. In many libraries, however, "not a forty-hour job" still means coming at eight and sitting still until five, rather than having the freedom to come and go in the way that is best for each library faculty member, whether other employees are envious or disapproving or not. Hill also remarks, accurately, that most librarians have a twelve-month contract, and are not free to pursue scholarship in the summer. ${ }^{26} \mathrm{M}$ ost libraries could probably afford to have a number of faculty on academic year contracts, however, and those that remain on twelve-month appointments probably have fewer demands in the summer, and could plan more scholarly activity for that time.

A ckerman quotes an analysis of the organization of a university library as stating that "the degree of formal supervision required by the library greatly exceeds that customary in the teaching colleges." 27 The librarians at this institution were uncertain about the prospects for a successful collegial organization for this reason. This is where the collegial and functional organizations meet, however, especially in technical services. A well-run technical services operation should not need library faculty to babysit. Experienced upper-level staff can be the best supervisors for the daily operations in technical services, leaving library faculty free to plan and execute the programmatic responsibility and engage in scholarship and governance as well.

Space is as great a factor as time. It was a revelation to me a number of years ago to hear a colleague remark on the eve of a library building project, "We' re the last faculty on campus who don't have offices." The new library included a separate office for each faculty member, because in the collegial organization, there may be a hierarchy concerning window offices or corner offices, but not in the fact that each scholar needs a private place to work. Lacking private offices, both technical and public services faculty suffer disadvantages. Public services librarians may be subject to a constant stream of traffic, whereas technical services librarians may have to work in a crowded warren of desks, undifferentiated from all other types and levels of staff, with their comings and goings more obvious and remarked on. M oreover, public services librarians perform reference and instruction at various designated places in the library. Technical services librarians have no "escape" from whatever space has been allotted to the department.

\section{INTERACTION WITH TEACHING FACULTY}

W hile public services librarians interact with teaching faculty during reference, instruction, and collection management activities, technical services librarians may have few opportunities for this kind of interaction. In the collegial organization, however, faculty have responsibilities that take them 
beyond the walls of their own department, and library faculty have a vital contribution to make in the way of university service. Faculty governance is carried out through a faculty senate and its standing and ad hoc committees. Library faculty have a broad intellectual outlook, organizational skills, and a view of the organization that is not limited to one college or department, which makes them valuable participants in university service.

While this kind of service is valuable for librarians and the university alike, it has another benefit for those who will take notice. The argument that librarians cannot be successful as faculty because our teaching colleagues will not accept us is belied by the behavior they show when participating on committees. They may not accept us as teachers, because we are not teachers. But if we are "wearing our own clothes," as Hill suggests, we will be accepted. Teaching faculty are as variable as any other group. They range from the dunce to the genius, and from the utterly provincial, who see the world from the perspective of their own department or discipline only, to those with a much broader perspective. Their view of library faculty is generally condescendingly uninterested at worst, to truly collegial at best. M oreover, it is naïve to believe that teaching faculty accept each other without reservation, and reject library faculty as unworthy. One hardy aspect of academic politics is the scorn of one department or discipline for another, and the pecking order that exists even in the same department between different sub-disciplines and individual faculty.

\section{CONCLUSION}

The collegial organization is better for a library, and particularly for technical services, than any functional organization by itself. The combination of functional expertise and the flexibility and broad outlook of the scholar are what allow the library "program" to be like the programs in a teaching department. In the view of Veaner, librarians have programmatic responsibility like that of teaching faculty for the curriculum. No organization makes people anything other than flawed, exasperating humans, but the collegial model frees the best people to do their best work.

\section{NOTES}

1. Allen B. Veaner. "Paradigm L ost, Paradigm Regained? A Persistent Personnel Issue in Academic Librarianship, II." College \& Research Libraries, 55, no. 5 (1994): 389-403.

2. Ibid., p. 393.

3. Ibid., p. 394.

4. For an interesting account of the governance issues facing academic librarians during the 1970s, see Page A ckerman, "Governance and A cademic Librarians," Library Research, 2 (M arch 1981): 3-28. 
5. A ssociation of College and R esearch Libraries. Committee on Faculty Status. F aculty Status for Academic Librarians: A H istory and Policy Statements. Chicago: A merican Library A ssociation, 1975.

6 . The workings of the academic department and the role of its chair are described in Allan Tucker, Chairing the Academic Department: Leadership Among Peers. 3rd ed. New York: A merican Council on Education, 1992 (The American Council on Education/M acmillan Series in Higher Education).

7. Ernest Boyer, Scholarship Reconsidered: Priorities of the Professoriate. Princeton, N.J.: Carnegie Foundation for the A dvancement of Teaching, 1990.

8. J anet Swan Hill, "Wearing O ur O wn Clothes: Librarians as Faculty." J ournal of Academic Librarianship, 20, no. 2 (1994): 73.

9. For a history of higher education in A merica and an account of the collegial and industrial characteristics of its organization, see Frederick Rudolph, The American College and U niversity: A History. New York: Vintage Books, 1962.

10. A llan Tucker, Chairing the Academic D epartment: Leadership among Peers. $3^{\text {rd }}$ ed. N ew Y ork: A merican Council on Education, 1992 (The A merican Council on Education/M acmillan Series in Higher Education).

11. A lex Bloss and Dona Lanier, "The Library Department Head in the Context of $M$ atrix $M$ anagement and Reengineering," College $\&$ Research Libraries, 58, no. 6 (1997): 499-507.

12. Bede W. M itchell and B ruce M orton, "On Becoming Faculty Librarians: Acculturation Problems and Remedies," College \& Research Libraries, 53, no. 5 (1992): 379-392.

13. Veaner, p. 384.

14. Hill, p. 71-76.

15. Rudolph, The American College and U niversity, p. 422.

16. Pauline Wilson, "Librarians as Teachers: The Study of an Organization Fiction," Library Quarterly, 49, no. 2 (1979): 146-162.

17. A ckerman, "Governance and A cademic Librarians," p. 11.

18. Hill, "Wearing Our Own Clothes," p. 72.

19. Julie J. M CG owan, "F Faculty Status and A cademic Librarianship: Transformation to a Clinical M odel," J ournal of Academic Librarianship, 2, no. 15 (1995): 345.

20. Veaner, "Paradigm L ost," p. 394.

21. Hill, "Wearing Our Own Clothes," p. 73.

22. C.S. Lewis, Studies in Words, $2^{\text {nd }}$ ed. (Cambridge: Cambridge University Press, 1996), p. 112.

23. Bruce R. Kingma and Gillian M . M cCombs, "The Opportunity Costs of Faculty Status for Academic Librarians," College \& Research Libraries, 56, no. 3 (1995): 258-267.

24. Hill, "Wearing Our Own Clothes," p. 74.

25. M itchell and M orton, "On Becoming Faculty Librarians," p. 389.

26. Hill, "Wearing Our Own Clothes," p. 74.

27. A ckerman, "Governance and A cademic Librarians," p. 14. 